\title{
The Divergence of Legal Procedures
}

\section{Citation}

Balas, Aron, Rafael La Porta, Florencio Lopez-de-Silanes, and Andrei Shleifer. 2009. "The

Divergence of Legal Procedures." American Economic Journal: Economic Policy 1 (2) (July): 138162. doi:10.1257/pol.1.2.138.

\section{Published Version}

doi:10.1257/pol.1.2.138

\section{Permanent link}

http://nrs.harvard.edu/urn-3:HUL.InstRepos:27867131

\section{Terms of Use}

This article was downloaded from Harvard University's DASH repository, and is made available under the terms and conditions applicable to Open Access Policy Articles, as set forth at http:// nrs.harvard.edu/urn-3:HUL.InstRepos:dash.current.terms-of-use\#OAP

\section{Share Your Story}

The Harvard community has made this article openly available.

Please share how this access benefits you. Submit a story.

Accessibility 
NBER WORKING PAPER SERIES

THE DIVERGENCE OF LEGAL PROCEDURES

\author{
Aron Balas \\ Rafael La Porta \\ Florencio Lopez-de-Silanes \\ Andrei Shleifer \\ Working Paper 13809 \\ http://www.nber.org/papers/w13809
}

\author{
NATIONAL BUREAU OF ECONOMIC RESEARCH \\ 1050 Massachusetts Avenue \\ Cambridge, MA 02138 \\ February 2008
}

The authors are grateful to Nicola Gennaioli, Louis Kaplow, and Giacomo Ponzetto for comments. Country-level sources of data are available from the authors upon request. The views expressed herein are those of the author(s) and do not necessarily reflect the views of the National Bureau of Economic Research.

NBER working papers are circulated for discussion and comment purposes. They have not been peerreviewed or been subject to the review by the NBER Board of Directors that accompanies official NBER publications.

(C) 2008 by Aron Balas, Rafael La Porta, Florencio Lopez-de-Silanes, and Andrei Shleifer. All rights reserved. Short sections of text, not to exceed two paragraphs, may be quoted without explicit permission provided that full credit, including $\odot$ notice, is given to the source. 
The Divergence of Legal Procedures

Aron Balas, Rafael La Porta, Florencio Lopez-de-Silanes, and Andrei Shleifer NBER Working Paper No. 13809

February 2008

JEL No. K4,K41,P51

\begin{abstract}
$\underline{\text { ABSTRACT }}$
Djankov et al. (2003a) propose and measure for 109 countries in the year 2000 an index of formalism of legal procedure for two simple disputes: eviction of a non-paying tenant and collection of a bounced check. For a sub-sample of 40 countries, we compute this index every year starting in 1950, which allows us to study the evolution of legal rules. We find that between 1950 and 2000, the formalism of legal procedure did not converge, and possibly diverged, between common law and French civil law countries. At least in this specific area of law, the results are inconsistent with the hypothesis that national legal systems are converging, and support the view that legal origins exert long lasting influence on legal rules.
\end{abstract}

\author{
Aron Balas \\ Oliver Wyman - Financial Services \\ 1 Neal Street \\ London, UK WC2H 9QL \\ balasa@nber.org \\ Rafael La Porta \\ Tuck School \\ 314 Woodbury \\ Hanover, NH 03755 \\ and NBER \\ rafael.laporta@dartmouth.edu
}

\author{
Florencio Lopez-de-Silanes \\ EDHEC Business School \\ 393, Promenade des Anglais BP 3116 \\ 06202 Nice Cedex 3, France \\ and NBER \\ Florencio.lopezdesilanes@edhec.edu
}

\author{
Andrei Shleifer \\ Department of Economics \\ Harvard University \\ Littauer Center M-9 \\ Cambridge, MA 02138 \\ and NBER \\ ashleifer@harvard.edu
}




\section{Introduction.}

Both the standard historical narrative and recent empirical research show that national legal systems vary systematically according to the legal traditions or origins which countries belong to. In particular, both substantive and procedural legal rules and regulations of civil (or Roman) law countries differ systematically from those of common (or English) law countries (Zweigert and Kotz 1998, La Porta et al. 1998, 1999, Djankov et al. 2002, 2003a, Botero et al. 2004). Following Damaska (1986), Glaeser and Shleifer (2002), and Djankov et al. (2003b), we have interpreted this broad range of findings as supportive of the Legal Origins Theory, the proposition that legal origins significantly shape the institutional structure of society, including the relationship between individuals and the state, and for this reason affect laws, legal procedures, regulations, as well as a broad range of economic outcomes (La Porta et al. 2008).

The observed variation raises a number of questions. Are these observed differences in laws and regulations merely a figment of recent data, or have they been present historically as well? Are the differences becoming larger or smaller over time? Are legal rules coming from different legal traditions converging?

Answers to these questions are central to the interpretation of legal origins. A finding that the observed end-of-the $20^{\text {th }}$-century differences are absent in historical data would undermine the importance of the Legal Origins Theory. Even if there are historical differences, convergence would suggest that the role of legal origins is diminishing, and therefore perhaps less should be made of them. In contrast, absence of convergence, or even divergence, would suggest that the effect of legal origins on legal and regulatory rules is long-lasting. In addition, we wish to know which factors - 
economic, political, or even internal to the legal system itself - determine the nature and the pace of legal change.

In this paper, we examine the design of the legal process for civil litigation in 40 countries between 1950 and 2000. We focus on civil procedure, defined as the "body of law concerned with methods, procedures and practices used in civil litigation” (Black, 1991). We follow Djankov et al. (2003a), who analyzed procedural rules governing the adjudication of simple legal disputes - the eviction of a non-paying tenant and the collection of a bounced check - for 109 countries in 2000. For each dispute in each country, Djankov et al. (2003a) computed “procedural formalism,” a measure of how heavily the law regulates the procedure. They then showed that procedural formalism is significantly higher in civil law (and particularly French civil law) than in common law countries, that higher formalism is associated with longer time to pursue a claim but not with greater perceived fairness of the process, and that formalism serves as a useful indicator of the inefficiency of the legal system.

Because data are vastly more limited going 50 years back, we here study only 40 generally somewhat richer than average countries, while making sure we cover all legal traditions (except socialist) and levels of economic development. Using the methodology of Djankov et al. (2003a), we measure procedural formalism for both disputes for each country every year between 1950 and 2000. We then look at the differences among legal traditions circa 1950 as well as 2000, at the convergence of procedural formalism across legal origins over time, as well as at the determinants of its evolution, including income, democracy, left-wing politics, and legal origins themselves. 
We focus on legal procedure for at least three distinct reasons. First, according to the comparative law scholars, legal procedure is the purest (perhaps the defining) expression of legal traditions (Damaska 1986, Zweigert and Kotz 1998). The nature of pleadings, the roles lawyers play, the approaches to collecting evidence, the importance of trial, the selection and function of judges, and so on are among the most basic features that differ among legal origins. According to the Legal Origins Theory, France and England have historically developed very different styles of social control of economic life, as well as legal institutions to support these styles. The civil law system was characterized by extreme concern with disorder, and an emphasis on extensive public regulation to counter it. Part of that regulation concerned the legal procedure itself, as the state sought to make sure that judges implemented its objectives (Damaska 1986, Glaeser and Shleifer 2002). The common law system, in contrast, was less focused on disorder, and more on restricting the power of the sovereign. Less formalized, more communitybased justice was part of this approach. As the two countries transplanted their legal systems through conquest and colonization, their different approaches to legal procedure became part of the broader legal families covering most of the world.

Second, Djankov et al. (2003a) have shown that our empirical characterization of legal procedures shapes economic outcomes and can indeed be used as an indicator of the efficiency of contract enforcement. To examine whether these relationships are merely an artifact of 2000 data, we have obtained estimates of contract enforcement over time.

Last, but not least, getting continuous data on legal rules over 50 years is challenging. We could not rely on practicing attorneys, as was done by Djankov et al. (2003a), since they are generally unfamiliar with historical data. The archives of major 
universities in the U.S., England and France, with additional borrowings from the Library of Congress, enabled us over several years to assemble data for legal procedures for 40 countries; a similar project in other areas of law might be even more complex.

The available legal scholarship concerning the convergence in legal procedures is sparse. Zekoll (2006) and Kerameus (1997) suggest that there has been convergence in legal procedures, at least within the EU, whereas Chase (2002) emphasizes the persistence of the fundamental differences between the English and the continental systems. There has also been a lively discussion of functional convergence in corporate law (Hansmann and Kraakman 2000, Gilson 2001), although recent evidence suggests that both formal legal rules and financial markets remain very different in common and civil law countries (La Porta et al. 2008, Enriques and Volpin 2007). The present paper is the first systematic empirical attempt to measure legal rules, and their convergence, for many countries over a long period of time.

In the next section, we describe our strategies of measurement and data collection. Section III then presents brief histories of civil procedures in 6 countries, which illustrate some of our findings. Section IV presents our basic fact: over the last 50 years, in our sample of 40 countries, for the two simple disputes we focus on, the formalism of the legal procedure has not on average converged, and possibly diverged, between common and civil law countries. The differences were large and significant in 1950, and expanded by 2000. Section IV also shows that there is divergence between legal origins within both the rich and the poor country sub-samples. Section V examines other determinants of the evolution of legal procedure; although some of them matter, the effect of legal origins remains statistically and economically significant. Section VI concludes. 


\section{Measuring Formalism}

Our analysis is based on a data set that tracks the evolution of the formalism of the legal procedure for adjudicating simple disputes in forty countries during the period 1950-2000. We combine data on the formalism of legal procedure in 2000 from Djankov et al. (2003a) with newly-collected data on its evolution between 1950 and 2000.

The formalism of legal procedure in 2000

Djankov et al. (2003a) relied on questionnaires answered by practicing attorneys at Lex Mundi and Lex Africa member firms in 109 countries. The questionnaires were designed to cover the step-by-step evolution of two simple civil suits: the collection of a bounced check and the eviction of a tenant for non-payment of rent. The chosen suits represented ordinary cases of default that are most likely to be relevant to many citizens, and were designed to be comparable regardless of a country’s culture or location.

The attorneys were instructed to describe the most common civil procedures used by litigants in practice, subject to detailed case facts. Specifically, for check collection the value of the claim is assumed to be 5\% of GNP per capita, while for tenant eviction one month's rent equals 5\% of GNP per capita with three months of rent in arrears. The claim is filed in 2000 in the country's largest city, where both parties reside. It is assumed that service of the process into the defendant's hands is not possible, but that notification of the proceedings is finally accomplished. In the check collection case, the plaintiff is also assumed to request provisional pre-trial attachment as a remedial measure if this is possible, and the court grants this request. Each party attempts to present documentary evidence and to call one witness, if possible, and the judge decides the case 
in favor of the plaintiff. No appeals or post-judgment motions are filed, and the plaintiff then takes all necessary steps for prompt enforcement of the judgment.

To measure formalism, Djankov et al. (2003a) began with a conceptual model of an ideal court where disputes between two neighbors are resolved by a third on fairness grounds (Shapiro 1981). Crucially, most states reject the neighbor model in favor of a more heavily regulated procedure. In part, they do so because they do not trust neighbors to reach decisions reflecting the state's interest in the outcome (Damaska 1986). In part, they are concerned that neighbors can be bribed or bullied by powerful litigants, and formalize procedure to reduce this risk (Glaeser and Shleifer 2002, 2003). Whatever the motivation for regulating legal procedure, the formalism index was designed to capture the extent of deviation from the neighbor model, where higher values indicated procedural systems that differ more from this model. Formalism is defined as the sum of seven sub-indices, which are briefly described below and formally defined in Table A1.

The first area measures the required degree of specialization of courts and professionalism of judges and lawyers. Because specialized courts generally have less formal rules and are aimed at bringing justice to the masses, these are assumed to be closer to the neighbor model than general courts. Similarly, nonprofessional judges and the absence of legal representation are closer to the neighbor model. The second area measures the predominance of written vs. oral elements in the proceeding. Since the neighbor model would rely on oral submissions, requirements for written submissions are accorded higher values in the formalism index. The third area measures the need for legal justification in the parties' motions and in court decisions, as well as basing the judgment in the law as opposed to equity. Requirements that court decisions be based 
exclusively on the law or that the parties present legal justification are deviations from the neighbor model. The fourth area measures the degree of statutory regulation of evidence. No restrictions on admissible evidence exist in the neighbor model, where the judge and parties could freely present and consider the evidence before reaching a decision. The fifth area refers to the control of the superior review of the first instance judgment. Automatic suspension of execution is considered to be a departure from the neighbor model. Similarly, comprehensive review and interlocutory appeals (those of interim judicial decisions) are also seen as departures from the neighbor model. The sixth area refers to the engagement formalities required for initiating the suit and notifying the parties of the proceedings. Such formalities are absent from the neighbor model, and therefore raise the formalism index. Finally, the seventh area measures the (normalized) minimum number of independent procedural actions required to complete the suit given the case facts.

Djankov et al. (2003a) aggregate their indicators from these seven areas into an overall index of procedural formalism of dispute resolution in each country. They find that, in 2000, such formalism is systematically higher in civil than in common law countries, and is associated with higher expected duration of judicial proceedings, and lower perceived consistency, honesty, and fairness of courts. Their results, however, provide no information about the history of procedural formalism.

The formalism of legal procedure since 1950

The primary empirical contribution of this paper is to compute the formalism index in 1950 for 40 countries and trace its evolution over the subsequent half-century. 
The choice of countries is dictated by the aim of covering all (but socialist) legal traditions in different regions and at various income levels. The non-socialist sub-sample covers 93 out of the original Djankov et al. (2003a) 109-country sample. For many of these, we simply could not find data from 1950. Since it took 2-3 weeks to process the initial data for each country, we stopped at 40 countries because we had some representation in all legal origins and income groups.

We start in 1950 because it marks the beginning of the post-war period, which witnessed significant political and economic changes across the world that had an important influence on civil justice. Since in 1950 some countries in the sample were still colonies and others had not yet completely reformed their legal systems due to other political arrangements (e.g. the British Commonwealth), we expect to find relatively less variation in formalism within legal origins in 1950 than in $2000{ }^{1}$

To measure formalism in 1950, we begin by reviewing all legislation and procedural rules applicable to the case facts in Djankov et al. (2003a). ${ }^{2}$ As in the 2000 data set, we code the procedure most likely to be used in practice given the remedies available under the law. If the set of possible procedures was the same in 1950 as in 2000, we choose the procedure suggested by the attorneys in the original questionnaires.

\footnotetext{
${ }^{1}$ In 1950, our sample includes British colonies of Belize, Botswana, Jamaica, Kenya, Malaysia, Nigeria, South Africa, Tanzania, and Uganda, and French colonies of Morocco, Tunisia, and Senegal, a total of 12.

${ }^{2}$ We retained the case assumptions used in the original 2000 coding. Thus, the case was assumed to take place in the country's largest city in 1950, with the value of the check and of one month's rent being $5 \%$ of GNP per capita in that year. We faced a few implementation challenges. First, for Tunisia and Senegal, the oldest source of legislation we found are for 1960 and 1965, respectively. For this reason, the formalism index has a few observations missing for Tunisia (1950-1959) and Senegal (1950-1964). Second, in 1950 many African former colonies maintained separate court hierarchies for natives and Europeans. We coded the procedure of the courts for Europeans, since those courts were ultimately used as the model for the entire court system. Third, in some countries, such as the Philippines, the monetary jurisdiction of certain courts was not raised in line with GNP per capita. In this case, unless the actual rules were amended, we keep track of changes in the procedure followed by the court that had jurisdiction at the end of the sample.
} 
If not, we choose the least costly option according to contemporaneous attorney practice manuals written by practitioners. If the practice manuals do not identify the least costly option, we choose the procedure that, if successful, would likely lead to the quickest possible outcome for the plaintiff. For example, in certain countries the plaintiff may request summary judgment if she believes the defendant has no credible defense. If the motion is successful, the court immediately decides in favor of the plaintiff without the need for a full trial. If this remedy exists in 1950 but not in 2000, and if the practice manuals for 1950 do not explicitly state which procedure is most common, then we assume the plaintiff would request summary judgment.

Having identified the procedure most likely to be used in 1950, coding is straightforward as formalism is primarily determined by statute. A key exception is that the number of required steps relies heavily on actual court practice. ${ }^{3}$ We use attorney manuals to determine the number of required steps but worry about measurement error since, unlike Djankov et al. (2003a), we cannot confirm this coding with practicing attorneys. For this reason, we have also constructed an alternative formalism index which excluded the number of steps; this index yielded very similar results. Our results are also robust to using the number of steps by itself as a measure of formalism.

Using the above procedure, one-coauthor measured the formalism index in 1950 and compiled a list of all the variables that changed between 1950 and 2000. This list guided us in the review of legislative history of procedural formalism for our two cases. This review helped determine the exact years when provisions were amended or replaced,

\footnotetext{
${ }^{3}$ For example, whether hearsay evidence is permitted is a question of statute, and does not vary according to practice. By contrast, whether the parties must usually appear at a separate hearing for presenting evidence, in which case it is a separate step, or whether evidence may be presented at the first hearing, in which case it is not, is a question of practice.
} 
or wider reforms took place. Another co-author then checked the data using the original sources. When we had trouble understanding the changes, the attorneys who participated in the original questionnaires were contacted for their guidance.

Figure 1 presents our first finding. Panel A shows the evolution of the 40-country average procedural formalism for tenant eviction between 1950 and 2000 and in Panel B, the same average for check collection. The obvious message of Figure 1 is that, for either tenant eviction or check collection, change over the 50 year period has been minimal, at least if we look at world averages. The 40-country average of the ratio of the 2000 to 1950 procedural formalism is 1.011 for tenant eviction, and 1.026 for check collection.

Looking at world averages, of course, hides a huge amount of heterogeneity. As Table 1 shows, our measure of procedural formalism shows large variation. For check collection, formalism fell (rose) by over 12\% (11\%) in 25 percent of the countries and by over $26 \%$ (28\%) in 10 percent of the countries. For tenant eviction, formalism fell (rose) by over $12 \%$ (15\%) in 25 percent of the countries and by almost 27\% (28\%) in 10 percent of the countries. We examine the sources of this heterogeneity in later sections.

\section{Case Studies.}

In this section, we present case studies of 6 sample countries, including 3 of French legal origin and 3 common law ones. The case studies are selected to illustrate the evolution of legal procedures in countries whose experiences point to general trends that will be verified in Section IV below.

\section{a) France}


Judicial procedure in pre-revolutionary France was seen as highly corrupt and inefficient. The revolutionaries abolished all existing courts of law. In their place, a new system of courts was established, in which minor matters were heard informally before a juge de paix (justice of the peace), and more serious matters were heard before a district court presided over by five judges. The Napoleonic Code confirmed this informal process for adjudicating small disputes. The 1806 codification maintained the fundamental distinction between the juges de paix, which were essentially arbitration courts with few formal rules and the ability to issue decisions based on general equity considerations, and the tribunaux civils, which were formal civil courts subject to a highly formalized written procedure.

In 1950, the French Code of Civil Procedure still looked very much like it did when it was enacted in 1806. Small-value claims such as the check collection and tenant eviction cases would have been heard before a juge de paix. Proceedings were quick and simple. As a result of this simplicity in procedural rules, procedural formalism was low for both cases (1.5 for checks and 2.17 for evictions).

Since 1950, there has been growing interest in the reform of French civil procedure, motivated by the concern that the existing system was both incapable of coping with the growing demand for justice and too expensive for the state because of a large number of judges. There were several efforts to reduce the number of courts. In 1958, there was a drastic consolidation of the judiciary, with 172 tribunaux de grande instance replacing 353 tribunaux civils and 455 tribunaux d'instance replacing 2092 juges de paix (Cadiet 1999, p. 315). The actual rules of procedure in these courts, however, remained the same for the time being. 
On January 1, 1977, a New Code of Civil Procedure completely replaced the 1806 code. A fundamental change in the New Code was the re-definition of the role of judges vis-à-vis the parties. Under the 1806 Code, the parties were given primary responsibility for the conduct of proceedings. In contrast, the New Code gave judges "extended powers and the responsibility to promote the public interest in the justice of the case, by reaching the fairest possible solution to the dispute" (Cadiet 1999, p.316). With regard to procedure, one of the Code's principle aims was simplification through standardization, which meant that there was no longer a separation between the rules governing small claims before the tribunaux d'instance (the successors to the juges de paix) and ordinary suits before the tribunaux de grande instance (the successors to the tribunaux civils). Instead, the New Code established a uniform set of rules that would be applicable to all courts and all jurisdictions unless otherwise provided by law. The new rules common to all jurisdictions were derived almost exclusively from the old rules governing the tribunaux civils, later the tribunaux de grande instance.

These changes increased legal formalism for simple disputes. In fact, there is now little difference in the procedures followed for small claims before the tribunaux d'instance and ordinary suits before the tribunaux de grande instance. In 1977, formalism grew from 1.5 to 2.71 for check collection and from 2.17 to 3.41 for tenant eviction. By 2000, the check collection procedure had a formalism index of 3.36, while the eviction procedure had a formalism index of $3.74 .^{4}$

\section{b) Mexico}

\footnotetext{
${ }^{4}$ In contrast, the adjudication of complex disputes probably got simpler. Cadiet writes, “The procedure has been simplified, by the suppression of exceptions and of the numerous irrational variations in procedure before each different court, most of which were inherited from history. Numerous rules became common to all jurisdictions.”
} 
The system established under Spanish colonial rule was not repealed when Mexico became independent. Following independence, Mexican jurists often relied on Spanish laws for inspiration in devising local legislation. This was particularly true of civil procedure, which even today is based largely on the Spanish Ley de Enjuiciamiento Civil of 1855.

The Civil procedure in place in Mexico City in 1950 was based on the Code of Civil Procedure for the Federal District of 1932. The 1932 Code maintained the traditional written rules for ordinary proceedings (juicio ordinario), but added a simplified procedure and greater orality for summary suits (juicio sumario). For minor suits (juicio sumarísimo) and very small claims before justices of the peace (justicia de paz), the procedure was much more rapid and almost entirely oral. An important feature of the 1932 Code - inherited from the Spanish legislation - was the summary eviction. For this reason, the proceedings for a non-payment of rent were considerably simpler than in ordinary suits or even in other types of summary suits.

Similarly to the consolidation in France in 1976, the special rules for summary suits were eventually abolished. Since 1973, nearly all civil suits must be tried using the formal rules established for ordinary suits. The motivation for this abolition was to provide greater flexibility to the courts, since it was considered that the simpler rules and shorter time periods prescribed for summary suits were too restrictive, and that it was better to have a single set of rules governing all suits (Fix-Zamudio, 1985).

The summary eviction suit was one of the few types of summary suits not impacted by the 1973 consolidation. This changed with the establishment of 15 housing judges by a decree dated 7 February 1985. A second decree dated 29 December 1986 
established a new summary procedure for suits arising out of residential tenancy contracts. The new residential tenancy procedure gradually replaced the old summary eviction procedure. These changes have been reflected in a significant rise in formalism for evicting a tenant (from 3.88 in 1950 to 5.04 in 2000).

In contrast to the tenant eviction case, the collection of unpaid bills of exchange in Mexico is governed by the Commercial Code's section on mercantile proceedings. This section of the Commercial Code, adopted in 1889, has changed remarkably little over the past 100 years. The procedure to collect a bounced check had a formalism index of 4.38 in 1950 and of 4.71 in 2000.

\section{c) Philippines}

Philippines is a French civil law country, with some common law influences imposed by the United States occupation forces. By the end of the $19^{\text {th }}$ century, the Spanish judicial system was firmly established in the Philippines, together with a complete set of laws and procedural rules governing all aspects of civil justice. Following the conclusion of the Spanish-American War in 1898, the administration of the Philippines transferred from Spain to the United States, until the country’s independence in 1934. After three and a half decades of direct American rule, the judicial system in the Philippines combined elements of Spanish and American law. The principal bodies of law that regulated civil relations remained basically Spanish, but court procedures by which these laws were enforced became almost wholly American.

This fusion of Spanish and American civil justice principles created a fairly simple judicial structure, in which most low-value claims were disposed of in the inferior courts, either the justices of the peace or the municipal courts in chartered cities. The 
1940 Rules of Court established a special set of rules for proceedings before the inferior courts that were substantially less formal than the ordinary rules in the courts of first instance. Eviction of a residential tenant in Manila in 1950 had a formalism index of 3.41. For small claims suits where the value did not exceed twenty pesos, the Rules of Court prescribed an even simpler procedure known as minor matter proceedings. The collection of a small bounced check in 1950 would have proceeded using these rules. This procedure had a formalism index of 2.56 .

Significant changes in civil justice began in the 1970s under the dictatorship of Ferdinand Marcos, who wanted to create a New Society safe from the threat of Communism. The President turned his attention to streamlining the Judiciary "for efficient delivery of services” (Narvassa 1998). In 1978, a Presidential Decree introduced the requirement that all litigants intending to bring a low-level civil claim must first attempt conciliation before the local Barangay Captain. Only if such conciliation failed could the plaintiff file a suit in the municipal or city court. While this change increased the level of formalism for cases that were brought to trial, there is evidence that required conciliation has had considerable success. ${ }^{5}$

In 1980, a new Judiciary Act abolished the courts of first instance, municipal courts, and city courts, and replaced them with regional trial courts and metropolitan trial courts. This was followed by a comprehensive overhaul of the civil procedural rules in 1983. That year, the Interim Rules and Guidelines abolished the procedural differences between inferior courts and ordinary courts. The same year, the new Rules on Summary Procedure replaced the earlier summary procedure provisions from the 1964 Rules of

\footnotetext{
${ }^{5}$ Between 1980 and 1990, 1,076,207 disputes were brought before the Barangay council for conciliation -$88.6 \%$ were successfully settled and only $6.7 \%$ were sent to the courts, with the other $4.7 \%$ still pending.
} 
Court. The new Rules increased the scope of summary procedures to include eviction proceedings, which had hitherto been excluded. The new Rules also stipulated that the provisions governing ordinary civil proceedings in the Rules of Court would also govern summary civil suits except where otherwise provided in the Rules on Summary Procedure. As a result of these changes, by 1985 formalism had increased to 4.99 (vs. 2.56 in 1950) for check collection and 5.13 (vs. 3.41 in 1950) for tenant eviction.

Following the end of the Marcos regime, the basic structure established by the Judiciary Act of 1980 and the Rules on Summary Procedure of 1983 continued to govern small claims civil justice until the end of the century.

\section{d) England}

The English civil procedure in 1800 was in many ways an outdated remnant of medieval developments that was of little use to ordinary people. Court proceedings were costly and complicated, and cases were often thrown out on technicalities. A fundamental distinction that still existed in 1800 was between law and equity. Common law courts were myriad and often had overlapping jurisdictions. ${ }^{6}$

In 1846, the County Courts Act established the county courts with jurisdiction to hear all claims up to $£ 20$ in value. In following decades, virtually all other borough and local courts were abolished as the jurisdiction of the county courts came to replace these earlier tribunals, leading to a more unified court system. The subsequent Judicature Acts of 1873 and 1875 together form the foundation of today's common law procedure throughout the former British Empire, excepting the United States. These Acts led to the

\footnotetext{
${ }^{6}$ Common law courts included the Court of King's Bench, the Court of Common Pleas and the Court of Exchequer, as well as a whole variety of specialised lower courts such as the Palatine Courts of the Duchy of Lancaster and the Counties of Chester and Durham, sheriffs' courts, justices of the peace and borough and local courts of record.
} 
establishment of the Court of Appeal as the Supreme Court of Judicature, as well as one single High Court of Justice that incorporated the former Courts of Chancery, King's Bench, Common Pleas, Exchequer, Probate, Divorce and Admiralty. Most importantly, the Judicature Acts stipulated that law and equity would henceforth be administered jointly, with equity prevailing in any case of conflict.

By 1950, the jurisdiction of the county courts had increased to $£ 200$ and their competence had been extended to include virtually any type of civil dispute. Because of prior concerns that plainly meritorious plaintiffs were often forced to endure unnecessarily long proceedings, the County Court Rules 1936 established two types of procedure: ordinary and default actions. In cases where a plaintiff did not believe the defendant had any defense, he could file a default summons which stipulated that judgment would be entered against the defendant automatically unless he contested the claim. The collection of a bounced check in 1950 would have in most cases proceeded as a default action, since this was the most common remedy for unpaid debts. Using the default summons procedure, the collection of a bounced check would have had a formalism level of 3.24. The tenant eviction case would have proceeded as an ordinary action because the relief claimed was not a simple debt. In this case, the level of formalism was 3.21.

An important problem with the county court system in 1950 was that there were still only two types of action, ordinary and default, with no separate provisions for small claims or summary judgment. Additionally, many of the rules of procedure and evidence were antiquated, and the standard terminology derived from Latin was largely inaccessible to those without legal education. In response to public dissatisfaction, major 
reform efforts began in the late 1960s and early 1970s. These reforms were aimed primarily at reducing the complexity and duration of civil suits. By 1980, the formalism index declined to 2.88 for check collection and 2.43 for tenant eviction.

In 1980, reference to arbitration became automatic for claims where the value did not exceed $£ 500$, thus establishing a truly separate procedure for handling small claims. In 1981, the new County Court Rules introduced for the first time the possibility of summary judgment for cases exceeding £500. These reforms were highly effective in reducing the number of cases brought to trial, and by 1994 the number of cases disposed of by arbitration exceeded the number going to trial by nearly 4 to $1 .^{7}$

In 1994, the Lord Chancellor appointed Lord Woolf to assist in reforming the civil justice system. These efforts culminated in the adoption of the Civil Procedure Rules in 1999, which radically changed in the fabric of English civil justice. The purpose of the new Rules was to reduce the length and complexity of civil suits, particularly for lowvalue claims. The reforms introduced a small claims track for low level disputes, raised the monetary limit for small claims, and allowed for a variety of alternative dispute resolution methods. As a result, procedural formalism, at 2.59 for check collection and 2.57 for tenant eviction, is lower today than it was in 1950 .

\section{e) Nigeria}

The English common law and court system was gradually introduced in Nigeria following the cession of Lagos to the Crown in 1861. In 1863, the English common law and rules for the administration of justice were formally made applicable to the colony, though only insofar as these were not incompatible with local laws and customs. The

\footnotetext{
${ }^{7}$ Although England and the Philippines undertook similar reforms requiring arbitration or a conciliation attempt first, the results were markedly different because the mere refusal to reconcile by the defendant makes the case proceed to full trial in the latter, whereas in England arbitration would still resolve the case.
} 
judicial structure established in Nigeria after unification in 1914 was based on the system inherited from the earlier Lagos colony and the courts of the Royal Niger Company.

By 1950, small-value claims such as the eviction of a residential tenant and the collection of a bounced check were subject to rules largely identical to those in the English county courts. In 1950, the value of the formalism index was 3.11 for check collection and 3.32 for tenant eviction. There has been remarkably little change in formalism since 1950 . In 2000, the value of the formalism index remained virtually unchanged for a bounced check dropping only to 3.10 but had a more considerable drop to 2.85 for an eviction.

\section{f) South Africa}

For the most part, the structure of civil justice existing today emerged in the late $19^{\text {th }}$ and early $20^{\text {th }}$ centuries, with the creation of the Union of South Africa as a selfgoverning dominion of the British Empire. Over time, the English court system and rules of pleading gradually replaced earlier Roman-Dutch practices, although certain elements from the pre-English period continue to influence civil proceedings to this day.

By 1950, the magistrates' courts system of South Africa strongly resembled the English county court system. This was particularly true for simple claims such as the eviction of a tenant or the collection of a bounced check, both of which were subject to more or less the same procedure in the magistrates' courts. Accordingly, the level of formalism in South Africa (3.56 for check collection and 3.87 for eviction) was comparable to that of England (3.24 and 3.21 for each case respectively).

Civil procedure has survived virtually unchanged since 1950. Much of the reform that has taken place has been aimed at further consolidation of the court system. The 
most important exception to this lack of reform was the establishment of the small claims courts in 1984 to hear simple debt cases. The new courts were established according to the same principles of speed and simplicity that governed their establishment in other common law countries. Hearings were to be quick and informal. There was no need for a formal written defense, and legal representation was prohibited. In addition, the usual rules of evidence would not apply in the small claims courts. As a result, by 1985 a check collection case had a formalism index of 1.65 . The formalism for tenant eviction remained close to its previous level at 3.69.

While these six case studies represent a small and intentionally chosen sample, they illustrate a possible generalization. Specifically, they suggest that between 1950 and 2000 the formalism of legal procedure has if anything diverged between common and civil law families. In the civil law countries, there appears to be a tendency to unify and standardize legal proceedings, which tends to increase formalism. In the common law countries, there appears to be a reverse tendency to create specialized, less formal tracks or courts for small claims in order to improve access to justice, which tends to reduce formalism. These distinct tendencies are evident in France and England; indeed France had a less formalized legal procedure than England for small claims in 1950, but experienced a sharp increase in formalism through unification afterwards. In the next section, we examine the broader validity of these hypotheses. 


\section{Divergence.}

Table 1 presents the basic data on legal formalism in 40 countries in 1950 and 2000 used in this paper. ${ }^{8}$ Our main findings can be gleaned from this Table and the accompanying figures. The central question of this paper is whether procedural formalism has on average converged among the legal origins. Figure 2 shows the path of procedural formalism for tenant eviction and check collection (panels A and B respectively). Panel A reveals four key points. The first two concern the levels of procedural formalism in 2000 and 1950, the second two address changes over time.

First, as of 2000, civil law countries have a sharply higher average level of procedural formalism for evictions than do common law countries (4.37 vs. 2.88), with a t-statistic of 5.91. This result is the same as that in Djankov et al. (2003a). Second, the same difference exists, but is slightly less pronounced, in 1950: the civil law average level of procedural formalism is 4.07 , compared to 3.21 for common law countries, with a t-statistic of 3.52 This result is crucial, as it shows that differences among legal origins are not merely an artifact of recent data; they were there 50 years ago as well.

Third, Panel A shows that procedural formalism for tenant eviction has, if anything, increased in civil law countries between 1950 and 2000, and declined in the common law countries. Among civil law countries, the average of the ratio of 2000 to 1950 procedural formalism is 1.103 , which is significantly higher than 1 (t-stat $=2.11)$. Among common law countries, the average of the ratio of 2000 to 1950 procedural formalism is .90 , which is significantly lower than 1 (t-stat $=2.44)$. Legal origin is a significant predictor of the change in procedural formalism over this 50 year period.

\footnotetext{
${ }^{8}$ The formalism index in 2000 in Table 1 incorporates feedback received from Lex-Mundi lawyers and legal scholars since the publication of Djankov et al. (2003a). The correlation between the formalism index in Table 1 and that in Djankov et al. (2003a) is .99.
} 
The fourth finding in Panel A of Figure 2 is obviously the consequence of the third, and is our most important one. Over the 50 year period, common and civil law countries diverged in their degree of procedural formalism for evictions. Quantitatively, the difference between civil and common law countries in the average ratios of 2000 to 1950 procedural formalism is 0.21 , with a t-statistic of 3.11. In these data, there is no evidence of convergence among legal origins, and some significant evidence of divergence. This result is broadly inconsistent with either the hypothesis that legal origins do not matter or the hypothesis that they matter less over time.

Panel B of Figure 2 presents similar results for check collection. In 2000, average procedural formalism is 4.25 in civil law countries, and 2.57 in common law ones, with the t-statistic of 5.59 on the difference. In 1950, average procedural formalism is 3.92 in civil law countries, compared to 2.92 in common law ones $(\mathrm{t}$-stat $=3.47)$. Procedural formalism increased in the civil law countries, with the average ratio of 2000 to 1950 procedural formalism of 1.14 (t-stat on the difference from 1 is 1.89). Procedural formalism declined in common law countries, with the average ratio of 2000 to 1950 formalism of .89 (t-stat on the difference from 1 is 2.06). Here, as for the case of tenant eviction, we see evidence of divergence between legal origins. The difference between legal origins of the average 2000 to 1950 ratios of procedural formalism is 0.26 , with a tstatistic of 2.65. In procedural formalism, legal families are moving apart, not together.

To conclude this section, we address two additional issues. First, one might raise the concern that in comparing formalism we merely look at legal origins, with no additional controls. To address this concern, Table 2 examines the cross-sectional determinants of procedural formalism in a regression format, but controls not just for 
legal origins but also for per capita income in the relevant year. Table 2 confirms the basic findings that, for both disputes, there are substantial differences among legal origins in procedural formalism both in 2000 and 1950. The parameter estimates for 1950 (respectively 2000) imply that a one-standard deviation increase in log income per capita is associated with a 0.28 (respectively 0.37 ) reduction in formalism. The effect of income per capita on formalism is modest compared with the -1.07 and -1.82 coefficients for common law in 1950 and 2000, respectively.

A second issue raised by this analysis is that, by pooling all countries within each legal tradition, we ignore the possibility that convergence patterns between legal origins differ within poor and rich country sub-samples. After all, when comparative legal scholars talk about convergence, they tend to emphasize the rich countries.

Panels A and B of Figure 3 show the evolution of procedural formalism for tenant eviction in each legal origin for countries with 1950 income per capita above and below $\$ 2,000$ ("rich” and "poor" countries) respectively. ${ }^{9}$ Figure 4 presents similar results for check collection. The results reveal no evidence of convergence among either the rich or the poor countries. This result is inconsistent with the view that the rich countries are converging and losing their legal identities because of globalization or European Union policies; even for these countries, the story is divergence.

The bottom line is that, at least in the area of legal procedures governing the adjudication of simple disputes, there has been no convergence among different legal families during 1950-2000. The differences among families existed in 1950, and have widened by 2000. At least for simple disputes, this evidence rejects the view that the

\footnotetext{
${ }^{9}$ In units of 1990 international dollars, the world mean income per capita in 1950 was roughly \$2,400. Alternative income-per-capita cutoffs produce similar results.
} 
influence of legal origins on legal procedure is a fin-de-siecle phenomenon. Moreover, for small disputes, this evidence also strongly rejects the view that globalization is quickly eroding the effect of legal origin on legal procedure. Instead, the evidence is supportive of the Legal Origins Theory, which holds that legal origins reflect deep structural attitudes in societies toward the relationship between the individual and the state, and as such exert long-lasting influence on legal rules and regulations.

\section{Determinants of Legal Evolution.}

In this section, we revisit the evidence of divergence from a different perspective, by asking what initial country characteristics determine the evolution of procedural formalism. Based on the previous section, legal origin is one candidate. But there are others, such as the level of economic development, education, political structure, and the political orientation of government. In this section, we evaluate these determinants.

The Legal Origins Theory predicts non-convergence in procedural formalism: it holds that procedural formalism is higher in civil law countries than in common law countries, and that the difference is long-lasting. We actually found some evidence of divergence in formalism across legal origins. Our case studies suggest one mechanical explanation of divergence over 1950-2000, namely that French civil law countries appear to have been unifying their court systems, and eliminating informal courts, while the common law countries were doing the opposite.

Another potential predictor of legal change is the level of economic development. Specifically, richer countries may undertake more legal reforms than poorer ones. Although this theory does not predict the direction of change in formalism, we saw in 
Figures 3 and 4 that the decline in formalism for common law countries was concentrated among the rich countries. However, the increase in formalism was slightly higher in the poor civil law countries than in the rich ones.

Economists have also proposed a set of arguments, not necessarily related to procedure, which hold that it is the political factors, rather than the structure of the legal system or the level of development, that influence legal evolution. For example, democracy or constraints on the executive might matter. It is not prima facie clear whether, for our simple disputes, the median voter wants more formalism (as he is more likely to be a debtor) or less formalism (as he benefits from more efficient contract enforcement). In any event, we can check what the data say. Also, we can check whether leftist politics had an influence on the evolution of legal procedure.

In all the specifications below, we try to explain legal evolution. Accordingly, the dependent variable is the ratio of 2000 to 1950 procedural formalism. In all specifications, we control for the initial procedural formalism to take into account possible mean reversion. We also pool the data for tenant eviction and check collection, and correct standard errors by appropriately clustering at the country level.

In Table 3, we consider how legal origins, initial level of economic development or initial education influence the evolution of procedure. First, we indeed have some evidence of mean reversion: initial formalism reduces the ratio. Second, richer countries, on average, reduced procedural formalism, holding legal origins constant. The same result holds for initial level of education (we cannot disentangle 1950 income from 1960 years of schooling). Richer or more educated countries reduced procedural formalism. 
Third, we confirm the result of section IV that common law countries, other things equal, reduced procedural formalism. Compared to civil law countries, depending on the specification, the ratio is a striking .37 to .41 lower and the effect is strongly significant. Divergence remains a robust message of the paper.

In Table 4, we include one at a time four political variables: two measures of democracy (the first being average democracy, the second being a stricter indicator of consistent perfect democracy - see Table A1), average constraints on the executive, and a measure of average leftist orientation of governments, which we have for the 1975-1995 period from Botero et al. (2004). Democracies and countries with more constrained executives reduced procedural formalism. A possible explanation is that, in democracies, the median voter sought to improve his access to courts. However, these results do not survive the inclusion of initial income as a control (results not reported). There is no evidence that leftist governments increased formalism. We have tried other political variables, such as proportional representation, divided government, union density, and leftist orientation of government since 1924, with no significant results. In our data, divergence is driven by legal origins, with other factors playing at best a secondary role.

\section{VI.Conclusion.}

This paper reports one basic finding: during 1950-2000, legal procedures of common and civil law countries governing the resolution of simple disputes have diverged. The particular disputes we considered are eviction of a non-paying tenant and the collection of a bounced check. We looked at 40 countries. And we used a particular 
index of legal procedure, the "formalism index" of Djankov et al. (2003a), which measures how tightly the law regulates the legal procedure itself.

The finding is inconsistent with the hypothesis that differences in legal procedure between legal families only existed at the end of the $20^{\text {th }}$ century; they are clearly more permanent. The data also rejects the hypothesis that legal families are exhibiting formal convergence. Indeed, we find divergence between families both in the whole 40-country sample, and in the rich and poor country sub-samples. At least for this area of law, then, the data are most consistent with the proposition that legal origins exert long-lasting influence on national legal rules.

Combined with the narratives, the statistical analysis we have presented suggests an interesting story. At the beginning of our sample, there is significant dissatisfaction with civil procedure in many countries of our sample. Access to justice is limited, while the administrative of justice is cumbersome and expensive. Yet countries react to this set of similar problems in radically different ways. Civil law countries, such as Mexico and France, unify their systems of civil justice, standardize procedure, and reduce the number of judges. The effect is to raise procedural formalism because the more streamlined channels are eliminated. Common law countries, actually led by New Zealand and Australia and followed by England, react to similar problems by creating cheaper and less formal mechanisms of resolving disputes, thereby reducing formalism. The suggested hypothesis is that an important difference between legal systems might be in how they react to problems. La Porta et al. (2008) push this hypothesis further; the data presented here might be part of a broader story. 
We should caution against over-generalizing these results. Our sample covered simple disputes; even with respect to legal procedure, the findings might be different for complex ones. Globalization and other forces of integration might bear relatively more strongly on substantive areas of law than they do on procedure. Finally, as argued by corporate law scholars, countries might exhibit substantive convergence in their legal rules without formal convergence (although it is not clear how this point would apply to procedure). Yet despite all these valid reservations, the paper has presented the first bit of systematic evidence against legal convergence for 40 countries over a 50 year horizon. 


\section{References}

Black, Henry Campbell. 1991. Black’s Law Dictionary. St. Paul, MN: West Publishing Co.

Botero, Juan, Simeon Djankov, Rafael La Porta, Florencio Lopez-de-Silanes, and Andrei Shleifer. 2004. “The regulation of labor.” Quarterly Journal of Economics 119(4): 1339-82.

Cadiet, Loïc. 1999. "Civil justice reform: access, cost, and delay. The French perspective.” In Zuckerman, Adrian A.S., ed. Civil Justice in Crisis: Comparative Perspectives in Civil Procedure. Oxford: Oxford University Press.

Chase, Oscar. 2002. “American "Exceptionalism" and comparative procedure.” The American Journal of Comparative Law 50(2): 277-301.

Damaska, Mirjan. 1986. The Faces of Justice and State Authority. New Haven, CT: Yale University Press.

Djankov, Simeon, Rafael La Porta, Florencio Lopez-de-Silanes, and Andrei Shleifer. 2002. “The regulation of entry.” Quarterly Journal of Economics 117(1): 1-37.

Djankov, Simeon, Rafael La Porta, Florencio Lopez-de-Silanes, and Andrei Shleifer. 2003a. “Courts.” Quarterly Journal of Economics 118(2): 453-517.

Djankov, Simeon, Edward Glaeser, Rafael La Porta, Florencio Lopez-de-Silanes, and Andrei Shleifer. 2003b. “The new comparative economics.” Journal of Comparative Economics 31(1): 595-619.

Enriques, Luca, and Paolo Volpin. 2007. “Corporate governance reforms in continental Europe.” Journal of Economic Perspectives 21(1): 117-40. 
Fix-Zamudio, Héctor. 1985. “La administración de justicia.” In Ovalle Favella, J ed. Temas y Problemas de la Administración de Justicia en México. $2^{\text {nd }}$ Ed. Mexico City: Miguel Ángel Porrúa.

Gilson, Ronald. 2001. “Globalizing corporate governance: convergence of form or function.” The American Journal of Comparative Law 49: 329-358.

Glaeser, Edward, and Andrei Shleifer. 2002. “Legal origins.” Quarterly Journal of Economics 117(4): 1193-1229.

Glaeser, Edward, and Andrei Shleifer. 2003. “The rise of the regulatory state.” Journal of Economic Literature 41(2): 401-425.

Hansmann, Henry, and Reinier Kraakman. 2000. “The end of history for corporate law.” The Georgetown Law Journal 89(438): 439-468.

Kerameus, Konstantinos. 1997. "Political integration and procedural convergence in the European Union”, The American Journal of Comparative Law 45(4): 919-930.

La Porta, Rafael, Florencio Lopez-de-Silanes, Andrei Shleifer, and Robert Vishny. 1998. “Law and finance.” Journal of Political Economy 106(6): 1113-55.

La Porta, Rafael, Florencio Lopez-de-Silanes, Andrei Shleifer, and Robert Vishny. 1999. “The quality of government.” Journal of Law, Economics, and Organization 15(1): 222-79.

La Porta, Rafael, Florencio Lopez-de-Silanes, and Andrei Shleifer. 2008. "The economic consequences of legal origins.” Journal of Economic Literature, forthcoming.

La Porta, Rafael, Florencio Lopez-de-Silanes, Christian Pop-Eleches, and Andrei Shleifer. 2004. “Judicial checks and balances.” Journal of Political Economy 112(2): 445-70. 
Narvasa, Andres. 1998. The History of the Philippine Judiciary. Manila: Philippine Judiciary Foundation.

Shapiro, Martin. 1981. Courts. Chicago, IL: The University of Chicago Press,

Zekoll, Joachim. 2006. “Comparative civil procedure.” In Reimann, Mathias, and Reinhard Zimmermann, The Oxford Handbook of Comparative Law. Oxford, New York: Oxford University Press.

Zweigert, Konrad, and Hein Kotz. 1998. Introduction to Comparative Law. Oxford: Clarendon Press. 
TABLE 1

Formalism Index between 1950 and 2000

This table classifies countries by legal origin. Panel A shows the formalism indices for the case of the eviction of a non-paying residential tenant and the collection of a bounced check in 1950, 2000, and the 2000/1950 ratio of each index. Panel B shows the t-statistics for the test of difference in means between common and civil law countries in our sample. All variables are described in Table $1 \mathrm{~A}$.

\begin{tabular}{|c|c|c|c|c|c|c|}
\hline \multirow{2}{*}{$\begin{array}{c}\text { Panel A: } \\
\text { Country }\end{array}$} & \multicolumn{3}{|c|}{ Eviction of a tenant } & \multicolumn{3}{|c|}{ Collection of a check } \\
\hline & $\begin{array}{l}\text { Formalism } \\
\text { Index } 1950\end{array}$ & $\begin{array}{l}\text { Formalism } \\
\text { Index } 2000\end{array}$ & $\begin{array}{c}\text { Formalism } 2000 \text { / } \\
\text { Formalism } 1950\end{array}$ & $\begin{array}{l}\text { Formalism } \\
\text { Index } 1950\end{array}$ & $\begin{array}{c}\text { Formalism Index } \\
2000\end{array}$ & $\begin{array}{c}\text { Formalism } 2000 \text { / } \\
\text { Formalism } 1950\end{array}$ \\
\hline \multicolumn{7}{|l|}{ Common Law countries } \\
\hline Australia & 2.817 & 2.007 & 0.712 & 2.667 & 1.777 & 0.666 \\
\hline Belize & 2.417 & 2.750 & 1.138 & 2.111 & 2.083 & 0.987 \\
\hline Canada & 3.500 & 2.347 & 0.671 & 2.431 & 2.064 & 0.849 \\
\hline Hong Kong & 2.825 & 3.505 & 1.241 & 2.792 & 0.706 & 0.253 \\
\hline India & 4.083 & 3.606 & 0.883 & 3.750 & 3.324 & 0.886 \\
\hline Jamaica & 2.342 & 2.366 & 1.010 & 2.375 & 2.346 & 0.988 \\
\hline Kenya & 3.392 & 2.940 & 0.867 & 3.111 & 3.072 & 0.987 \\
\hline Malaysia & 3.400 & 3.310 & 0.974 & 2.944 & 2.324 & 0.789 \\
\hline New Zealand & 2.046 & 1.352 & 0.661 & 1.544 & 1.554 & 1.006 \\
\hline Nigeria & 3.317 & 2.852 & 0.860 & 3.111 & 3.099 & 0.996 \\
\hline South Africa & 3.867 & 3.690 & 0.954 & 3.556 & 1.652 & 0.465 \\
\hline Sri Lanka & 3.258 & 3.801 & 1.167 & 2.996 & 3.630 & 1.212 \\
\hline Tanzania & 3.508 & 2.727 & 0.777 & 3.347 & 3.549 & 1.060 \\
\hline USA & 3.225 & 2.838 & 0.880 & 2.319 & 2.623 & 1.131 \\
\hline Uganda & 2.783 & 1.787 & 0.642 & 2.950 & 2.585 & 0.876 \\
\hline United Kingdom & 3.214 & 2.565 & 0.798 & 3.242 & 2.587 & 0.798 \\
\hline Mean & 3.207 & 2.883 & 0.898 & 2.921 & 2.571 & 0.886 \\
\hline Median & 3.288 & 2.845 & 0.879 & 2.973 & 2.586 & 0.949 \\
\hline \multicolumn{7}{|l|}{ Civil law countries } \\
\hline Argentina & 4.575 & 5.681 & 1.242 & 4.431 & 5.332 & 1.203 \\
\hline Austria & 3.482 & 3.686 & 1.059 & 3.204 & 3.502 & 1.093 \\
\hline Belgium & 2.292 & 3.222 & 1.406 & 2.319 & 3.162 & 1.364 \\
\hline Bolivia & 4.375 & 5.250 & 1.200 & 5.194 & 5.744 & 1.106 \\
\hline Colombia & 4.175 & 4.139 & 0.991 & 3.333 & 3.980 & 1.194 \\
\hline France & 2.167 & 3.741 & 1.726 & 1.500 & 3.360 & 2.240 \\
\hline Germany & 3.575 & 3.694 & 1.033 & 3.264 & 3.358 & 1.029 \\
\hline Italy & 5.642 & 4.236 & 0.751 & 5.177 & 4.019 & 0.776 \\
\hline Japan & 3.958 & 3.731 & 0.943 & 3.319 & 2.954 & 0.890 \\
\hline Mexico & 3.875 & 5.042 & 1.301 & 4.375 & 4.708 & 1.076 \\
\hline Morocco & 3.833 & 4.810 & 1.255 & 3.806 & 5.148 & 1.353 \\
\hline Netherlands & 3.275 & 3.046 & 0.930 & 3.208 & 3.047 & 0.950 \\
\hline Peru & 4.767 & 5.546 & 1.163 & 5.375 & 5.592 & 1.040 \\
\hline Philippines & 3.408 & 5.130 & 1.505 & 2.556 & 4.986 & 1.951 \\
\hline Portugal & 5.033 & 4.644 & 0.923 & 4.514 & 4.116 & 0.912 \\
\hline Senegal & 4.417 & 4.287 & 0.971 & 4.278 & 5.041 & 1.178 \\
\hline Spain & 5.200 & 4.995 & 0.961 & 5.611 & 5.445 & 0.970 \\
\hline Sweden & 3.425 & 3.370 & 0.984 & 2.847 & 2.964 & 1.041 \\
\hline Tunisia & 3.558 & 3.468 & 0.975 & 3.653 & 3.483 & 0.953 \\
\hline Venezuela & 5.305 & 5.802 & 1.094 & 5.155 & 5.808 & 1.127 \\
\hline Civil law mean & 4.072 & 4.370 & 1.103 & 3.923 & 4.248 & 1.141 \\
\hline Civil law median & 4.067 & 4.262 & 1.012 & 4.042 & 4.068 & 1.059 \\
\hline Mean for all countries & 3.683 & 3.701 & 1.011 & 3.472 & 3.493 & 1.026 \\
\hline Median for all countries & 3.533 & 3.688 & 0.974 & 3.291 & 3.359 & 0.992 \\
\hline \multicolumn{7}{|c|}{ Panel B: Tests of means (t-stats) } \\
\hline Common vs Civil Law & 3.520 & 5.905 & 3.109 & 3.464 & 5.585 & 2.643 \\
\hline
\end{tabular}


TABLE 2

Cross-sectional determinants of procedural formalism

The table shows OLS regressions for the cross-section of countries. The dependent variables are the formalism index in 1950 and in 2000. We pool the observations for the cases of eviction of a tenant and check collection, and report standard errors clustered at the country level. Robust standard errors are shown in brackets. All variables are defined in Table 1A.

\begin{tabular}{|c|c|c|c|c|}
\hline \multirow[b]{2}{*}{ Log GDP per capita in 1950} & \multicolumn{2}{|c|}{$\begin{array}{c}\text { Dependent variable: } \\
\text { Formalism index } 1950\end{array}$} & \multicolumn{2}{|c|}{$\begin{array}{l}\text { Dependent variable: } \\
\text { Formalism index } 2000\end{array}$} \\
\hline & $\begin{array}{l}-0.2756^{\mathrm{b}} \\
{[0.122]}\end{array}$ & $\begin{array}{l}-0.2463^{\mathrm{C}} \\
{[0.132]}\end{array}$ & & \\
\hline Log GDP per capita in 2000 & & & $\begin{array}{l}-0.3685^{\mathrm{a}} \\
{[0.086]}\end{array}$ & $\begin{array}{l}-0.3119^{\mathrm{a}} \\
{[0.087]}\end{array}$ \\
\hline Common law dummy & $\begin{array}{c}-1.0681^{\mathrm{a}} \\
{[0.229]}\end{array}$ & & $\begin{array}{l}-1.8171^{\mathrm{a}} \\
{[0.214]}\end{array}$ & \\
\hline French civil law dummy & & $\begin{array}{l}1.1744^{\mathrm{a}} \\
{[0.260]}\end{array}$ & & $\begin{array}{l}1.9217^{\mathrm{a}} \\
{[0.229]}\end{array}$ \\
\hline German civil law dummy & & $\begin{array}{l}0.5442^{\mathrm{a}} \\
{[0.148]}\end{array}$ & & $\begin{array}{l}1.2280^{\mathrm{a}} \\
{[0.184]}\end{array}$ \\
\hline Scandinavian civil law dummy & & $\begin{array}{l}0.4106^{\mathrm{c}} \\
{[0.226]}\end{array}$ & & $\begin{array}{l}0.9066^{\mathrm{a}} \\
{[0.174]}\end{array}$ \\
\hline Constant & $\begin{array}{l}6.1830^{\mathrm{a}} \\
{[0.924]}\end{array}$ & $\begin{array}{l}4.8964^{\mathrm{a}} \\
{[0.972]}\end{array}$ & $\begin{array}{l}7.7044^{\mathrm{a}} \\
{[0.810]}\end{array}$ & $\begin{array}{l}5.4015^{\mathrm{a}} \\
{[0.783]}\end{array}$ \\
\hline $\begin{array}{l}\text { Observations } \\
\text { R-squared }\end{array}$ & $\begin{array}{c}80 \\
0.30\end{array}$ & $\begin{array}{c}80 \\
0.34\end{array}$ & $\begin{array}{c}80 \\
0.58\end{array}$ & $\begin{array}{c}80 \\
0.61\end{array}$ \\
\hline
\end{tabular}




\section{TABLE 3}

\section{Evolution of procedural formalism: initial income, initial education and legal origins}

The table shows OLS regressions for the cross-section of countries. The dependent variable is the ratio of the formalism index in 2000 over the formalism index in 1950. We pool the observations for the cases of eviction of a tenant and check collection, and report standard errors clustered at the country level. Robust standard errors are shown in brackets. All variables are defined in Table 1A.

\begin{tabular}{|c|c|c|c|c|}
\hline Dependent variable: & \multicolumn{4}{|c|}{ Formalism index 2000 / Formalism index 1950} \\
\hline Formalism index 1950 & $\begin{array}{c}-0.1669^{\mathrm{a}} \\
{[0.058]}\end{array}$ & $\begin{array}{c}-0.1884^{\mathrm{a}} \\
{[0.055]}\end{array}$ & $\begin{array}{c}-0.1845^{\mathrm{a}} \\
{[0.064]}\end{array}$ & $\begin{array}{c}-0.1918^{\mathrm{a}} \\
{[0.061]}\end{array}$ \\
\hline Log GDP per capita in 1950 & $\begin{array}{c}-0.07492^{b} \\
{[0.036]}\end{array}$ & $\begin{array}{c}-0.07061^{\mathrm{C}} \\
{[0.036]}\end{array}$ & & \\
\hline Years of schooling in 1960 & & & $\begin{array}{c}-0.02896^{\mathrm{b}} \\
{[0.014]}\end{array}$ & $\begin{array}{c}-0.02041 \\
{[0.013]}\end{array}$ \\
\hline Common law dummy & $\begin{array}{c}-0.4227^{\mathrm{a}} \\
{[0.101]}\end{array}$ & & $\begin{array}{c}-0.4057^{\mathrm{a}} \\
{[0.102]}\end{array}$ & \\
\hline French civil law dummy & & $\begin{array}{l}0.4870^{\mathrm{a}} \\
{[0.107]}\end{array}$ & & $\begin{array}{c}0.4512 \mathrm{a} \\
{[0.113]}\end{array}$ \\
\hline German civil law dummy & & $\begin{array}{l}0.2320^{\mathrm{a}} \\
{[0.062]}\end{array}$ & & $\begin{array}{l}0.2629^{\mathrm{a}} \\
{[0.070]}\end{array}$ \\
\hline Scandinavian civil law dummy & & $\begin{array}{l}0.2311^{\mathrm{a}} \\
{[0.061]}\end{array}$ & & $\begin{array}{l}0.2116^{\mathrm{a}} \\
{[0.057]}\end{array}$ \\
\hline Constant & $\begin{array}{l}2.3837^{\mathrm{a}} \\
{[0.451]}\end{array}$ & $\begin{array}{l}1.9948^{\mathrm{a}} \\
{[0.356]}\end{array}$ & $\begin{array}{l}1.9795^{\mathrm{a}} \\
{[0.331]}\end{array}$ & $\begin{array}{l}1.5584^{\mathrm{a}} \\
{[0.227]}\end{array}$ \\
\hline Observations & 80 & 80 & 72 & 72 \\
\hline R-squared & 0.40 & 0.47 & 0.41 & 0.44 \\
\hline
\end{tabular}




\section{TABLE 4}

\section{Evolution of procedural formalism: politics and legal origins}

The table shows OLS regressions for the cross-section of countries. The dependent variable is the ratio of the formalism index in 2000 over the formalism index in 1950. We pool the observations for the cases of eviction of a tenant and check collection, and report standard errors clustered at the country level. Robust standard errors are shown in brackets. All variables are defined in Table 1A.

Dependent variable:

\begin{tabular}{|c|c|c|c|c|}
\hline Formalism index 1950 & $\begin{array}{c}-0.1684^{\mathrm{a}} \\
{[0.060]}\end{array}$ & $\begin{array}{c}-0.1860^{\mathrm{a}} \\
{[0.062]}\end{array}$ & $\begin{array}{c}-0.1654^{\mathrm{a}} \\
{[0.059]}\end{array}$ & $\begin{array}{c}-0.1546^{\mathrm{a}} \\
{[0.057]}\end{array}$ \\
\hline Common law dummy & $\begin{array}{c}-0.3654^{\mathrm{a}} \\
{[0.094]}\end{array}$ & $\begin{array}{c}-0.3735^{\mathrm{a}} \\
{[0.096]}\end{array}$ & $\begin{array}{c}-0.3476^{\mathrm{a}} \\
{[0.090]}\end{array}$ & $\begin{array}{c}-0.4085^{\mathrm{a}} \\
{[0.099]}\end{array}$ \\
\hline Democracy (1950-2000) & $\begin{array}{c}-0.01655^{\mathrm{c}} \\
{[0.009]}\end{array}$ & & & \\
\hline Democracy dummy & & $\begin{array}{c}-0.1438^{\mathrm{c}} \\
{[0.072]}\end{array}$ & & \\
\hline Executive constraints (1950-2000) & & & $\begin{array}{c}-0.03249^{\mathrm{c}} \\
{[0.019]}\end{array}$ & \\
\hline Left/center government (1975-1995) & & & & $\begin{array}{c}0.1037 \\
{[0.077]}\end{array}$ \\
\hline Constant & $\begin{array}{l}1.8930^{\mathrm{a}} \\
{[0.293]}\end{array}$ & $\begin{array}{l}1.9181^{\mathrm{a}} \\
{[0.291]}\end{array}$ & $\begin{array}{l}1.9394^{\mathrm{a}} \\
{[0.321]}\end{array}$ & $\begin{array}{l}1.7011^{\mathrm{a}} \\
{[0.253]}\end{array}$ \\
\hline Observations & 76 & 76 & 76 & 76 \\
\hline R-squared & 0.43 & 0.44 & 0.43 & 0.40 \\
\hline
\end{tabular}

Formalism index 2000 / Formalism index 1950

$-0.1438$

[0.072]

.03249

$1.7011^{\mathrm{a}}$

1.8930

1.9181

$1.9394^{\mathrm{a}}$

76

76

0.40 
Figure 1:

Evolution of Formalism (1950-2000)

Panel A: Tenant Eviction (Average for all countries)

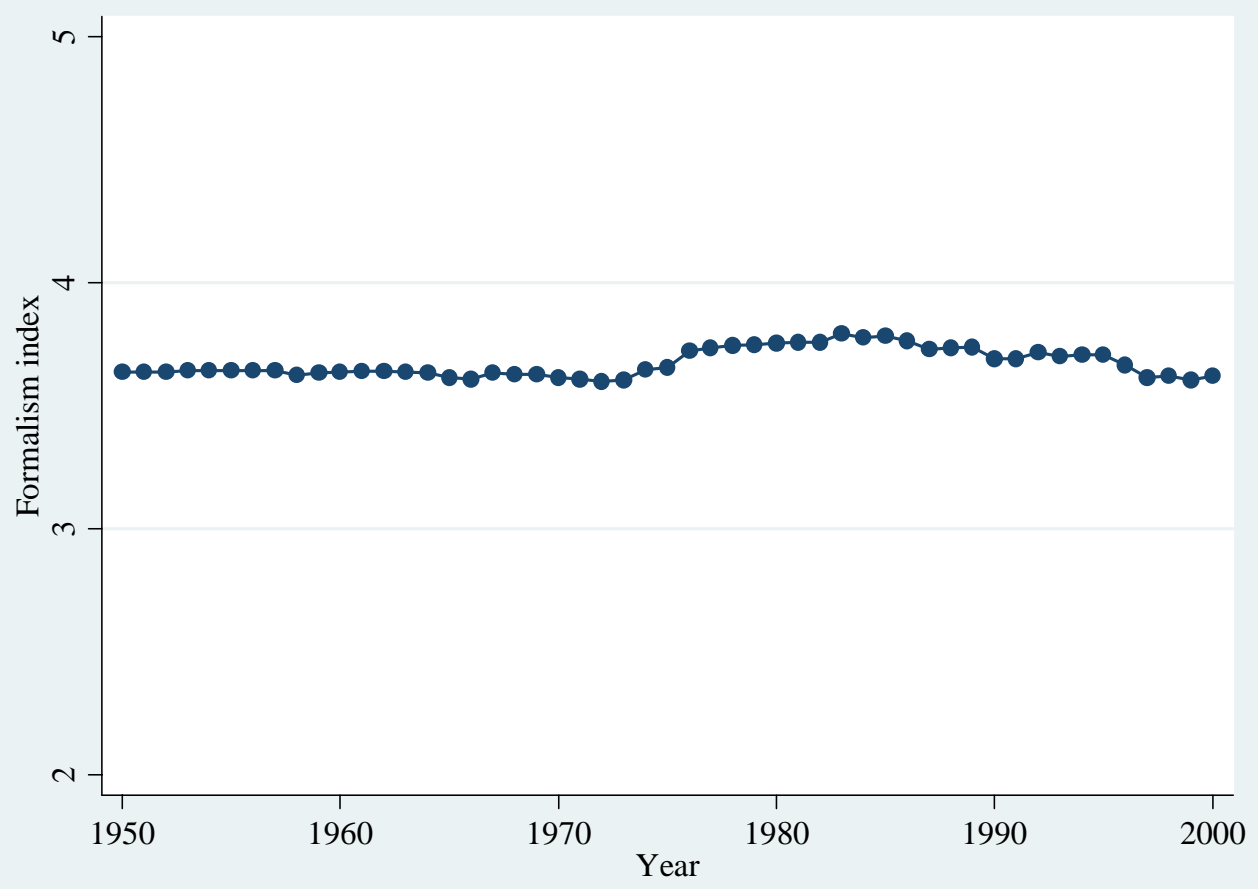

Panel B: Check Collection (Average for all countries)

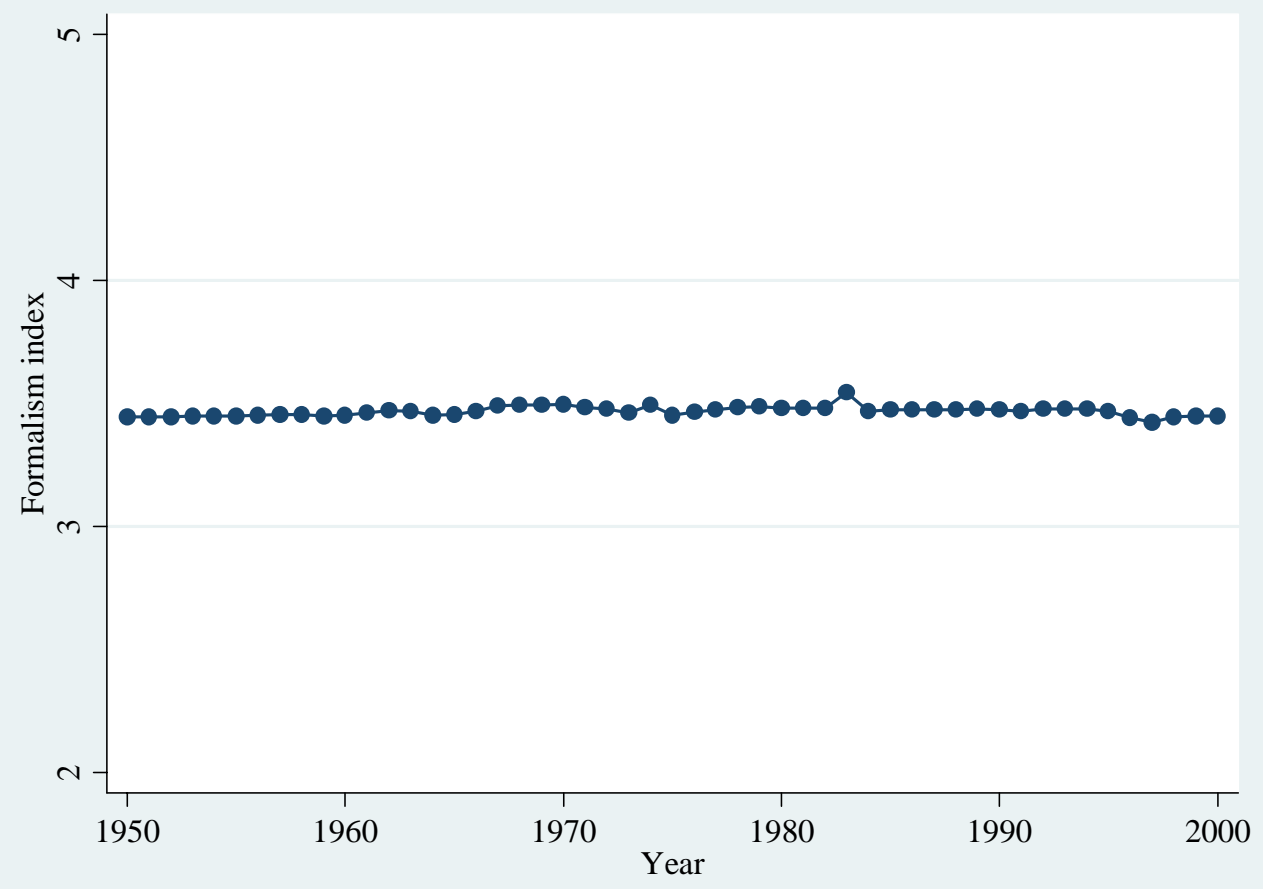


Figure 2:

Evolution of Formalism Across Legal Origins (1950-2000)

\section{Panel A: Tenant Eviction}

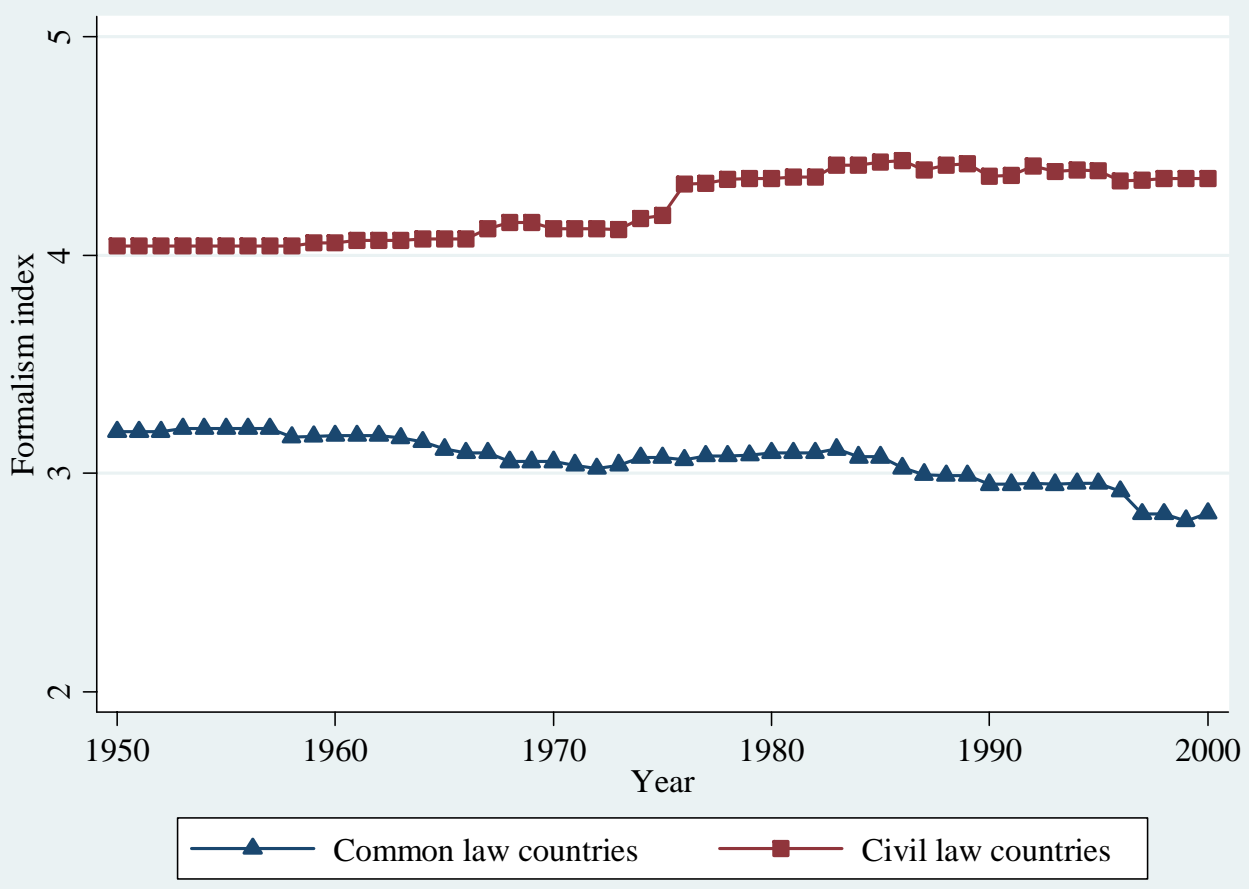

Panel B: Check Collection

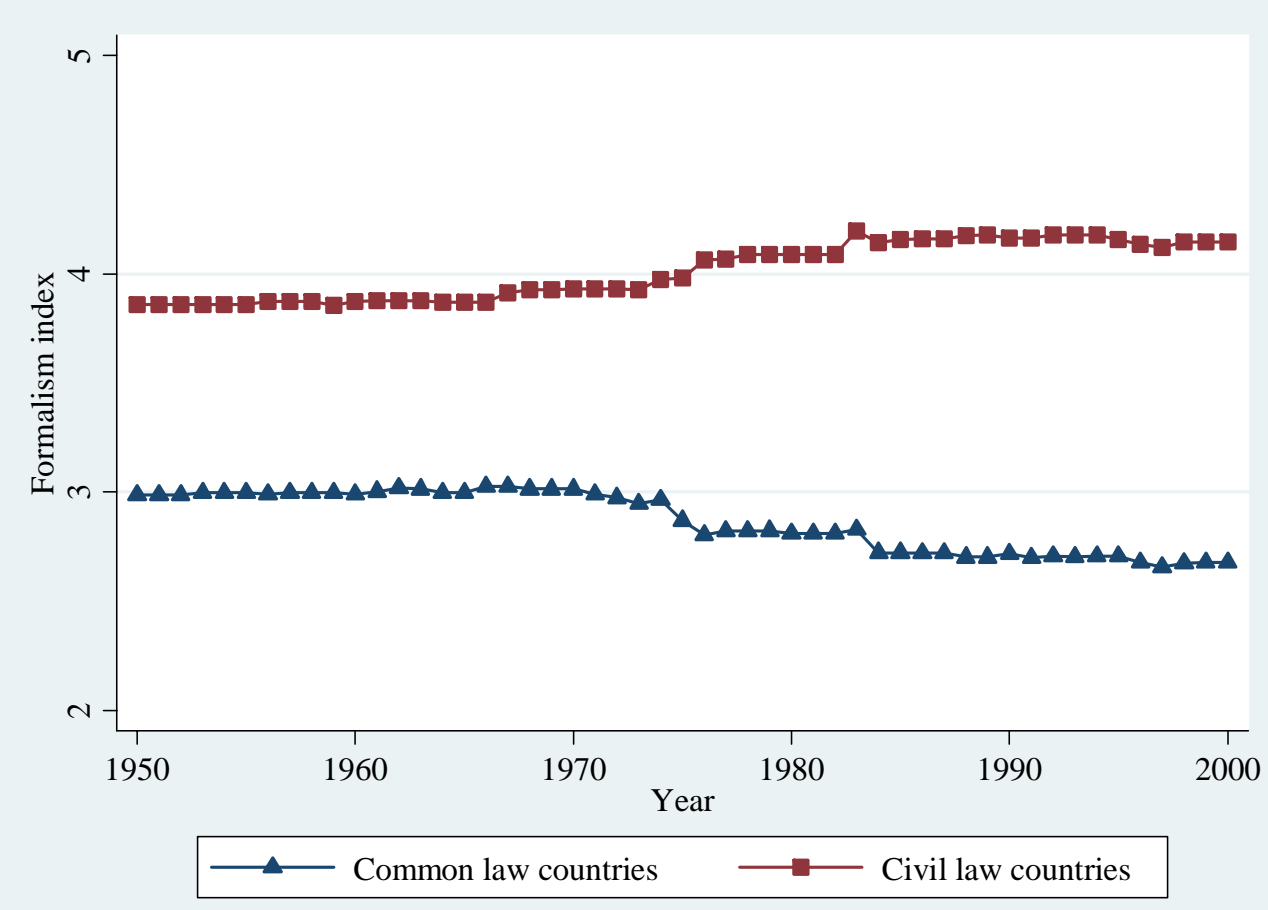


Figure 3:

Evolution of Formalism by Income Level

Tenant Eviction (1950-2000)

Panel A: High GDP per capita countries in 1950

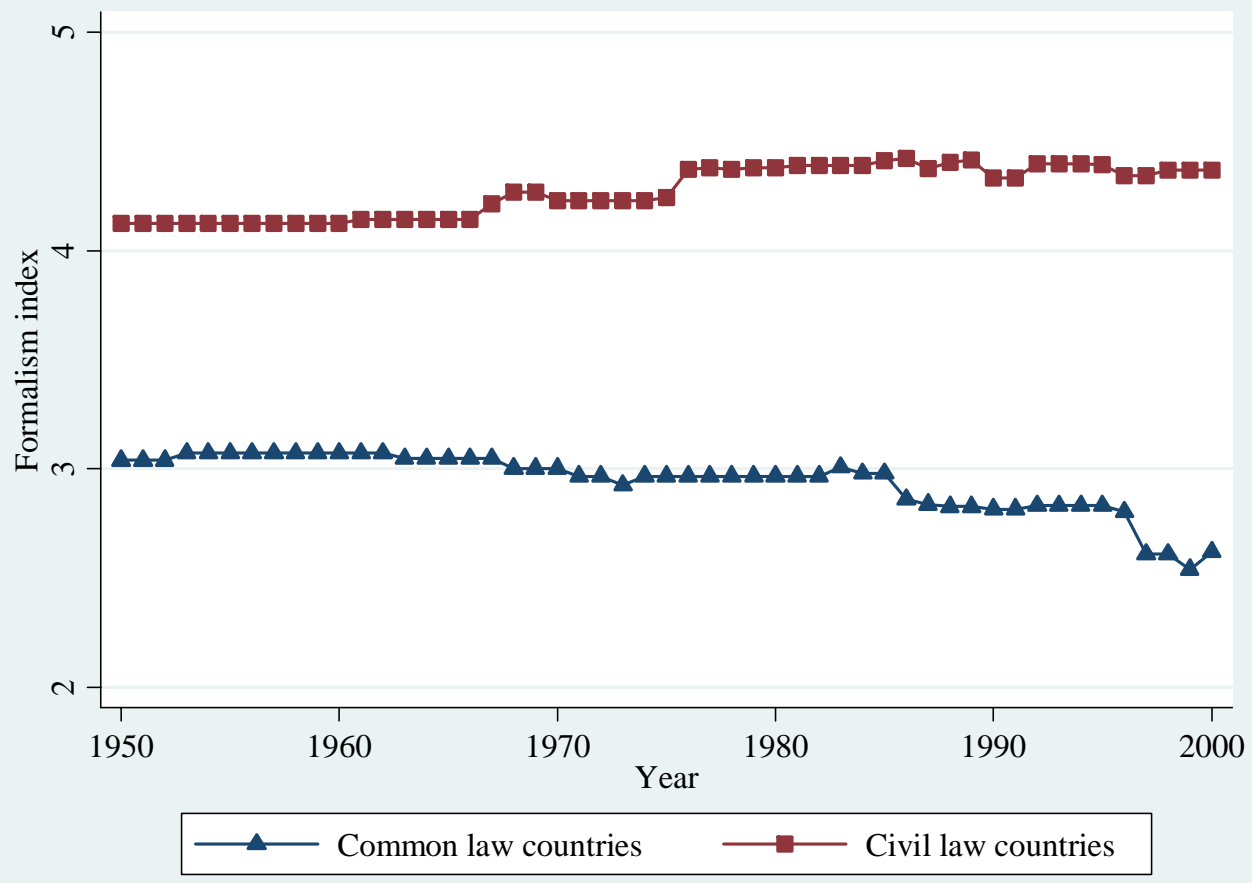

Panel B: Low GDP per capita countries in 1950

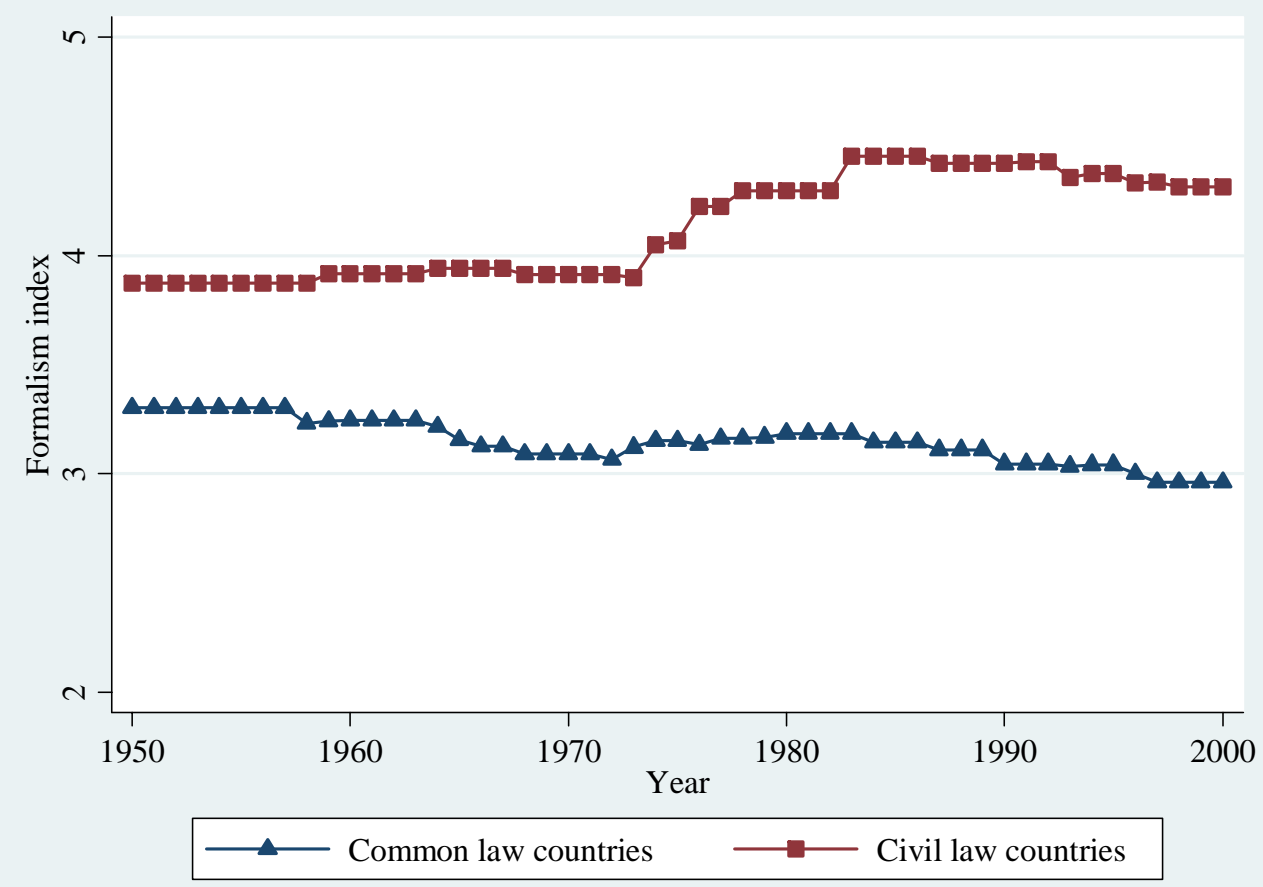


Figure 4:

Evolution of Formalism by Income Level

Check Collection (1950-2000)

Panel A: High GDP per capita countries in 1950

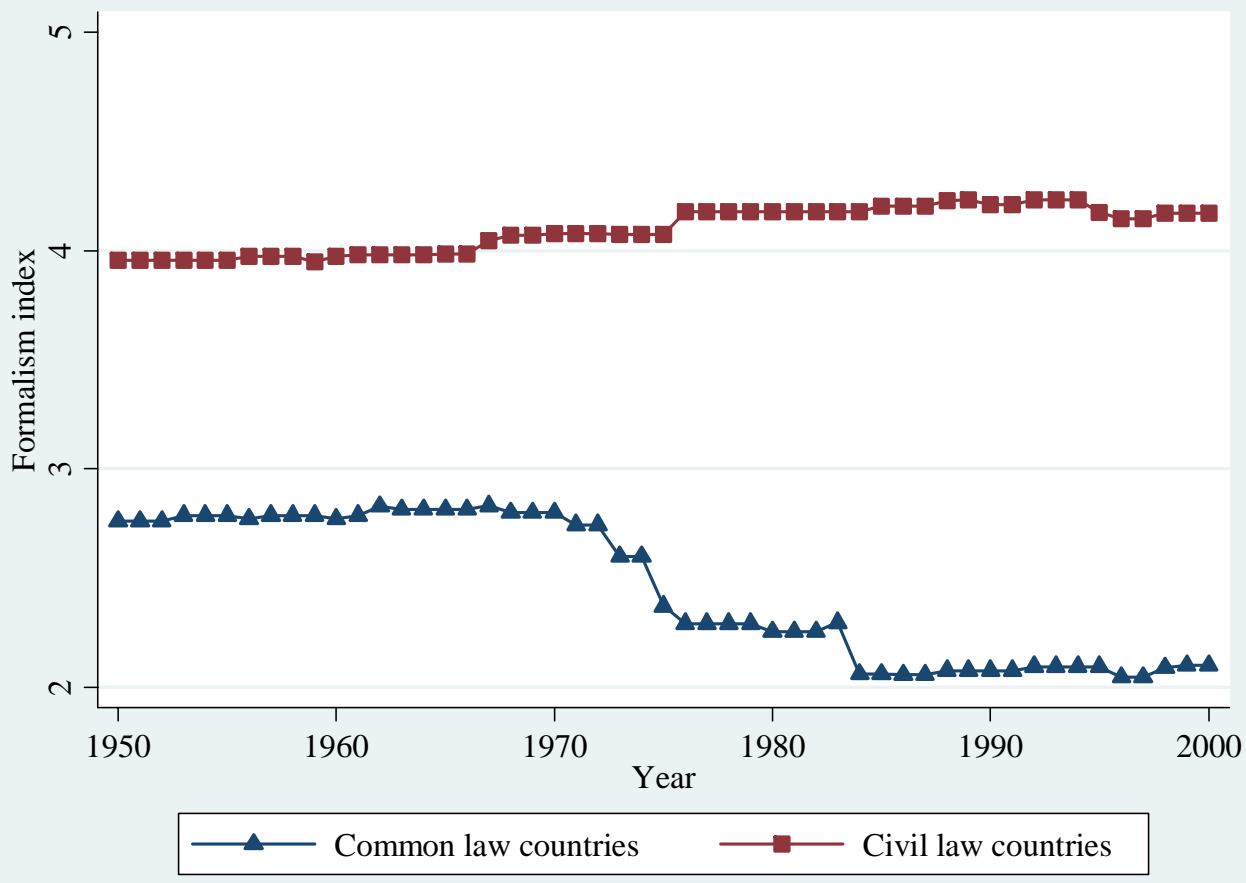

Panel B: Low GDP per capita countries in 1950

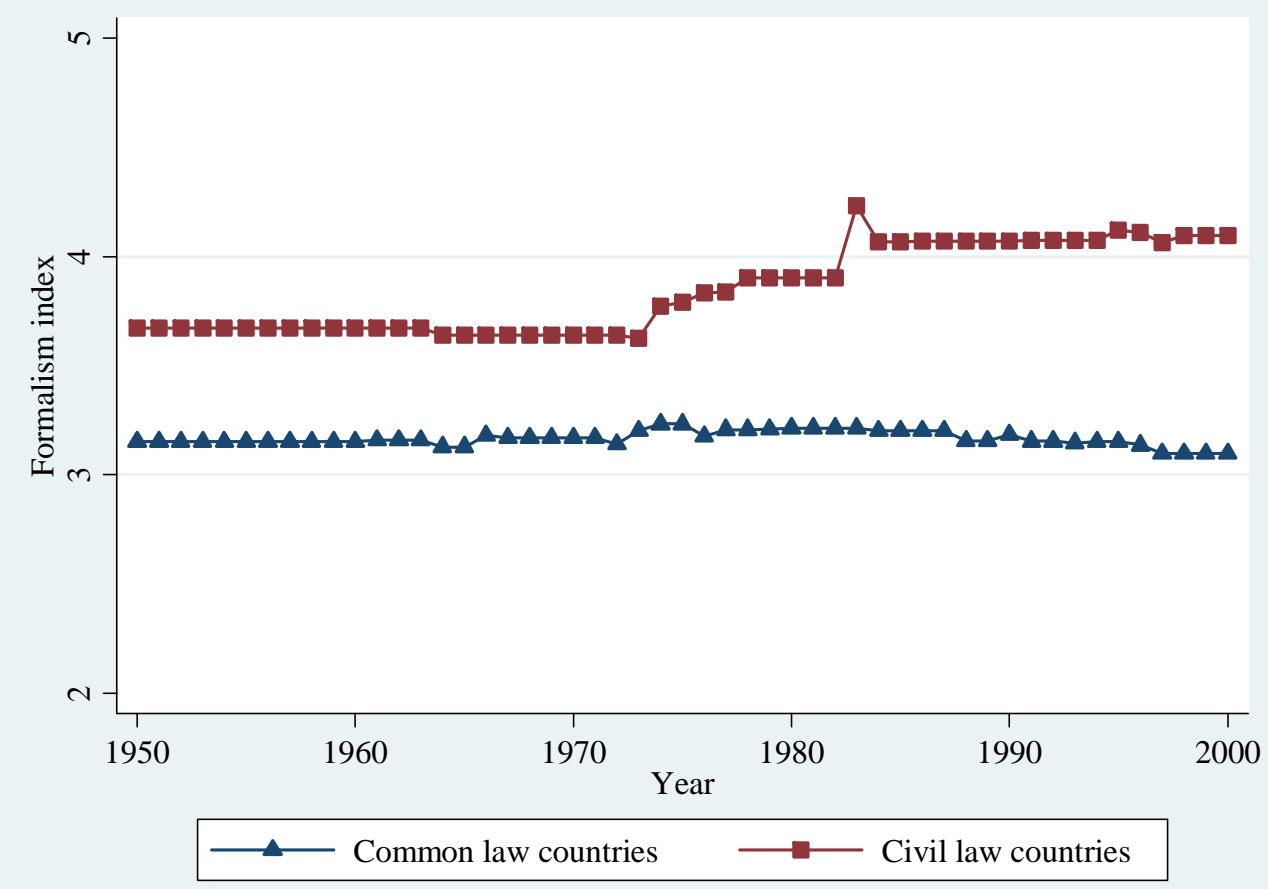




\section{Table 1A: Appendix Description of the variables}

This table describes the variables in the paper.

\begin{tabular}{ll}
\hline \hline Variable & Description \\
\hline
\end{tabular}

Economic variables

Log GDP per capita

Legal origin

Years of schooling in 1960

Democracy

Democracy dummy

Executive constraints

Left/center government

Formalism index
Logarithm of gross domestic product per capita in units of international Geary-Khamis dollars of 1990. Source: Maddison (2003).

Identifies the legal origin of the company law or commercial code of each country (English, French, Socialist, German, and Scandinavian). This variable is also used to generate the classification of countries in common law (i.e., English legal origin) and civil law families. Source: La Porta, et al. (1999).

Average years of schooling in 1960 of the total population over 25 years of age. Source: Barro, Robert J. and Jong-Wha Lee, International Data on Educational Attainment: Updates and Implications. Source: Barro and Lee (2000) Data posted on http://www.cid.harvard.edu/ciddata/ciddata.html

A measure of the degree of democracy in a given country based on: (1) the competitiveness of political participation; (2) the openness and competitiveness of executive recruitment; and (3) the constraints on the chief executive. The variable ranges from zero to ten, where higher values equal a higher degree of institutionalized democracy. This variable is calculated as the average from 1950 through 2000. Source: Jaggers and Marshall (2000) and updates.

Equals 1 if democracy is higher than 8, and zero otherwise. Under this definition, the democracy dummy equals one for: Botswana, Canada, France, Germany, India, Italy, Jamaica, Japan, Netherlands, New Zealand, Sweden, United States of America, and the United Kingdom. The data source does not include data for Belize and Hong Kong, so we have assigned a missing value for these two countries. Source: Own construction based on data from Jaggers and Marshall (2000) and updates.

A measure of the extent of institutionalized constraints on the decision making powers of chief executives. The variable takes seven different values: (1) Unlimited authority (there are no regular limitations on the executive's actions, as distinct from irregular limitations such as the threat or actuality of coups and assassinations); (2) Intermediate category; (3) Slight to moderate limitation on executive authority (there are some real but limited restraints on the executive); (4) Intermediate category; (5) Substantial limitations on executive authority (the executive has more effective authority than any accountability group but is subject to substantial constraints by them); (6) Intermediate category; (7) Executive parity or subordination (accountability groups have effective authority equal to or greater than the executive in most areas of activity). This variable ranges from one to seven where higher values equal a greater extent of institutionalized constraints on the power of chief executives. This variable is calculated as the average from 1950 through 2000. Source: Jaggers and Marshall (2000) and updates.

Percentage of year between 1975 and1995, during which both the party of the chief executive and largest party in congress have left or center political orientation. If the country was not independent in 1975, the initial year of the period, we use the independence year as the first period. For countries that were part of a larger country in 1975 and subsequently broke-up, we include in calculations the political orientation of the political parties in the mother country in the pre-breakup period. In the case of military regimes, where political affiliations are unclear, we classify the regime based on its policies. Source: Botero et al (2004).

\section{Formalism index}

Index of substantive and procedural statutory intervention in judicial cases at lower-level civil trial courts for each year between 1950 and 2000. The index is formed, as in Djankov et al (2003), by adding up the following indices: (i) professionals vs. laymen; (ii) written vs. oral elements; (iii) legal justification; (iv) statutory regulation of evidence; (v) control of superior review; (vi) engagement formalities; and (vii) independent procedural actions. The index ranges from 0 to 7 , where 7 means a higher level of control or intervention in the judicial process. Some of the components of the index are defined differently than in Djankov et al (2003). For this reason, we provide the revised definition of the components of the index below. Source: Authors' own calculations based on Djankov et al (2003). 
General jurisdiction court

Professional vs. nonprofessional judge

Legal representation is Mandatory

Index: Professionals vs. laymen.

Filing

Service of process

Opposition

Evidence

Final arguments

Judgment

Notification of judgment

Enforcement of judgment

Index: Written vs. oral elements

Complaint must be legally justified

Judgment must be legally Justified

Judgment must be on law (not on equity)
Equals 1 if a court of general or of limited jurisdiction would be chosen or assigned to hear the case under normal circumstances, and zero otherwise. We define a court of general jurisdiction as a state institution, recognized by the law as part of the regular court system, generally competent to hear and decide regular civil or criminal cases. A limited jurisdiction court would hear and decide only some types of civil cases. Specialized debt-collection or housing courts, small-claims courts, and arbitrators or justices of the peace are examples.

Equals 1 if the judge (or members of the court or tribunal) are professionals, and zero otherwise. A professional judge is one who has undergone a complete professional training as required by law, and whose primary activity is to act as judge or member of a court. A non-professional judge is an arbitrator, administrative officer, practicing attorney, merchant, or any other layperson who may be authorized to hear and decide the case.

Equals 1 when legal representation by a licensed attorney is mandatory and zero otherwise.

The index measures whether the resolution of the case relies on the work of professional judges and attorneys, as opposed to other types of adjudicators and lay people. The index is the normalized sum of: (i) general jurisdiction court, (ii) professional vs. non-professional judge, and (iii) legal representation is mandatory. The index ranges from 0 to 1 , where higher values mean more participation by professionals.

\section{Written vs. oral}

Equals one if the complaint is normally submitted in written form to the court, and zero otherwise.

Equals one if the defendant's first official notice of the complaint is most likely received in writing, and zero otherwise.

Equals one if under normal circumstances the defendant's answer to the complaint is normally submitted in writing, and zero otherwise.

Equals one if most of the evidence, including documentary evidence, is submitted to the court in written form, in the form of attachments, affidavits, or other written documents, and zero otherwise.

Equals one if final arguments on the case are normally submitted in writing, and zero otherwise.

Equals one if normally the parties receive an official notification of the final decision in written form, by notice mailed to them, publication in a court board or gazette, or through any other written means, and zero otherwise.

Equals one if normally the parties receive their first notice of the final decision in written form, by notice mailed to them, publication in a court board or gazette, or through any other written means, and zero otherwise.

Equals one if the enforcement procedure is mostly carried out through the written court orders or written acts by the enforcement authority, and zero otherwise.

The index measures the written or oral nature of the actions involved in the procedure, from the filing of the complaint until the actual enforcement. The index is calculated as the number of stages carried out mostly in written form over the total number of applicable stages, and it ranges from 0 to 1 , where higher values mean higher prevalence of written elements.

\section{Legal justification}

The variable measures whether the complaint is required, by law or usual court practice, to include references to the applicable laws, legal reasoning, or formalities beyond a simple statement of the particulars of claim. Equals one for a legally justified complaint, and zero when the complaint does not ordinarily require legal justification (specific articles of the law, case-law, etc).

The variable measures whether the judgment is normally expected to expressly state the legal justification (articles of the law, case-law, etc) for the decision. Equals one for a legally justified judgment, and zero otherwise.

Equals 1 if the judgment is normally motivated and founded on the law, and zero otherwise. 
Index: Legal justification

Judge cannot introduce evidence

Judge cannot reject

irrelevant evidence

Out-of-court statements are inadmissible

Mandatory pre-qualification of questions

Oral interrogation only by judge

Only original documents and certified copies are admissible

Authenticity and weight of evidence defined by law

Mandatory recording of evidence

Index: Statutory regulation of evidence
The index measures the level of legal justification required in the process. The index is formed by the normalized sum of: (i) complaint must be legally justified, (ii) judgment must be legally justified, and (iii) judgment must be on law (not on equity). The index ranges from 0 to 1 , where higher values mean a higher use of legal language or justification.

\section{Statutory regulation of evidence}

Equals one if, by law, the judge cannot freely request or take evidence that has not been requested, offered, or introduced by the parties, and zero otherwise.

Equals one if, by law, the judge cannot refuse to collect or admit evidence requested by the parties, even if she deems it irrelevant to the case, and zero otherwise.

Equals one if statements of fact that were not directly known or perceived by the witness, but only heard from a third person, may not be admitted as evidence, and zero otherwise.

Equals one if, by law, the judge must pre-qualify the questions before they are asked of the witnesses, and zero otherwise.

Equals one if by law, parties and witnesses can only be orally interrogated by the judge, and zero otherwise.

Equals one if by law, only original documents and "authentic" or "certified" copies are admissible documentary evidence, and zero otherwise.

Equals one if the authenticity and probative value of documentary evidence is specifically defined by the law, and zero if all admissible documentary evidence is freely weighted by the judge.

Equals one if, by law, there must be a written or magnetic record of all evidence introduced at trial, and zero otherwise.

The index measures the level of statutory control or intervention of the administration, admissibility, evaluation and recording of evidence. The index is formed by the normalized sum of the following variables : (i) judge can not introduce evidence, (ii) judge cannot reject irrelevant evidence, (iii) out-of-court statements are inadmissible, (iv) mandatory pre-qualification of questions, (v) oral interrogation only by judge, (VI) only original documents and certified copies are admissible, (vii) authenticity and weight of evidence defined by law, and (viii) mandatory recording of evidence. The index ranges from 0 to 1 , where higher values mean a higher statutory control or intervention.

\section{Control of Superior Review}

Equals one if the enforcement of judgment is automatically suspended until resolution of the appeal when a request for appeal is granted, and zero otherwise.

automatically suspended until resolution of the appeal

Comprehensive review in appeal

Interlocutory appeals are allowed

Index: Control of superior review

Equals one if issues of both law and fact (evidence) can be reviewed by the appellate court, and zero otherwise.

Equals one if interlocutory appeals are allowed, and zero otherwise. Interlocutory appeals are defined as appeals against interlocutory or interim judicial decisions made during the course of a judicial proceeding in first instance and before the final ruling on the entire case.

The index measures the level of control or intervention of the appellate court's review of the first-instance judgment. The index is formed by the normalized sum of the following variables: (i) enforcement of judgment is automatically suspended until resolution of appeal, (ii) comprehensive review in appeal, and (iii) interlocutory appeals are allowed. The index ranges from 0 to 1, where higher values mean higher control or intervention.

\section{Engagement formalities}

Equals one if the law requires plaintiff to attempt a pre-trial conciliation or mediation before filing the lawsuit, and zero otherwise.
Mandatory pre-trial conciliation 


\section{Variable}

Service of process by judicial officer required

Notification of judgment by judicial officer required

Index: Engagement formalities

Filing and service

Trial and judgment

Enforcement

Index: Independent procedural actions

\section{Description}

Equals one if the law requires the complaint to be served to the defendant by a judicial officer, and zero otherwise.

Equals one if the law requires the judgment to be notified to the defendant by a judicial officer, and zero otherwise.

The index measures the formalities required to engage someone in the procedure or to held him/her accountable of the judgment. The index is formed by the normalized sum of the following variables: (i) mandatory pre-trial conciliation, (ii) service of process by judicial officer required, and (iii) notification of judgment by judicial officer required. The index ranges from 0 to 1 , where higher values mean a higher statutory control or intervention in the judicial process.

\section{Independent procedural actions}

The total minimum number of independent procedural actions required to complete filing, admission, attachment, and service.

The total minimum number of independent procedural actions required to complete opposition to the complaint, hearing or trial, evidence, final arguments, and judgment.

The total minimum number of independent procedural actions required to complete notification and enforcement of judgment.

An independent procedural action is defined as a step of the procedure, mandated by law or court regulation, that demands interaction between the parties or between them and the judge or court officer (e.g., filing a motion, attending a hearing, mailing a letter, or seizing some goods). We also count as an independent procedural action every judicial or administrative writ, resolution or action (e.g., issuing judgment or entering a writ of execution) which is legally required to advance the proceedings until the enforcement of judgment. Actions are always assumed to be simultaneous if possible, so procedural events that may be fulfilled in the same day and place are only counted as one action or step. To form the index, we: (1) add the minimum number of independent procedural actions required to complete all the stages of the process (from filing of lawsuit to enforcement of judgment); and (2) normalize this number to fall between zero and one using the minimum and the maximum number of independent procedural actions among the countries in the sample. The index ranges from 0 to 1 , where higher values are associated with more procedural actions. 